\title{
Pulmonary Embolism Associated with Pandemic H1N1 Influenza A Virus Infection: a Case Report
} \author{
Mehmet Kadir Bartın ${ }^{4}$ \\ ${ }^{1}$ Department of Gastroenterology, Faculty of Medicine, Yüzüncü Yıl University, Van, Turkey \\ ${ }^{2}$ Department of Radiology, Faculty of Medicine, Yüzüncü Yıl University, Van, Turkey \\ ${ }^{3}$ Department of Chest Diseases, Faculty of Medicine, Yüzüncü Yıl University, Van, Turkey \\ ${ }^{4}$ Department of General Surgery, Faculty of Medicine, Yüzüncü Yıl University, Van, Turkey
}

Ahmet Cumhur Dülger1', Serhat Avcu², Harun Arslan², Bülent Özbay³, Hülya Günbatar³, Mehmet Emin Küçükoğlu¹,

\begin{abstract}
On May 15, 2009, the Turkish Ministry of Health reported the first case of 2009 pandemic influenza A (H1N1) virus infection in the Republic of Turkey. Pandemic H1N1virus is a new and mutant influenza virus and has many epidemiologic and clinic features. These cases have been reported in multiple geographic regions of the world. School children are more affected than adults. In the elderly, it has a higher mortality rate. The clinical aspects of infection with $\mathrm{H} 1 \mathrm{~N} 1$ influenza A virus remains to be understood. A few cases of pulmonary embolism associated with $\mathrm{H} 1 \mathrm{~N} 1$ influenza A virus infection were reported. We herein report a pulmonary embolism in a patient with pandemic influenza A (H1N1) virus infection. A 42-year-old Turkish woman was admitted to our emergency department with dyspnea and pleuritic chest pain. She complained of fever, myalgia, sore throat and cough of four days duration on admission to our hospital. She was tested for pandemic influenza $A$ (H1N1) virus by a polymerase chain reaction (PCR) test which revealed a positive result. Chest tomography showed pulmonary embolism. She was successfully treated with intravenous heparin and oseltamivir. This case report demonstrates the importance of considering pulmvonary embolism as a diagnosis in 2009 pandemic influenza A (H1N1) virus infected persons who present with sudden onset of dyspnea, fever and chest pain.
\end{abstract}

Key Words: Pandemic influenza A (H1N1) virus, pulmonary embolism

Received: 19.12.2009

Accepted: 23.03.2010

\section{Introduction}

Pandemic influenza $A(\mathrm{H} 1 \mathrm{~N} 1)$ virus seems to have originated from a combination of the North American swine virus with the NA and $M$ segments of a European swine virus (1).

In Mid-Spring of 2009, an outbreak of H1N1 influenza A virus infection was detected in Mexico, with subsequent cases reported in many other countries $(2,3)$. The majority of cases of pandemic $\mathrm{H} 1 \mathrm{~N} 1$ virus were relatively mild and uncomplicated (4). Typical clinical manifestations include fever, headache, cough, sore throat, myalgias, chills and fatigue. Vomiting and diarrhea have also been common, both of which are unusual features of seasonal influenza. During the 2009 pandemic, rapidly progressive pneumonia, respiratory failure, acute respiratory distress syndrome and pulmonary embolism were reported in some cases (5). The purpose of this report is to highlight the risk of pulmonary embolism in a case of pandemic H1N1 influenza A infection.

\section{Case}

A 42-year-old Turkish woman presented to our emergency department with fever, dyspnea and pleuritic chest pain. She complained of fever, myalgia, sore throat, and cough starting four days before admission to hospital. There was no history of thrombosis, abortus, recent physical trauma, or prolonged air travel. Examination in the emergency room revealed a heart rate of $80 \mathrm{bpm}$, a respiratory rate of 35 breaths per minute and a blood pressure of $125 / 79 \mathrm{~mm} \mathrm{Hg}$. The maximum temperature was $38.6{ }^{\circ} \mathrm{C}$. Pulse oximetry was $85 \%$. Physical examination showed no clear abnormality in the lungs. A loud pulmonic component of the second heart sound was heard on auscultation. The findings of the remainder of the physical examination were within normal limits.

Her serum alanine transaminase, aspartate transaminase and lactate dehydrogenase were elevated to $45 \mathrm{IU} / \mathrm{I}$ (normal range <35 IU/I), $60 \mathrm{IU} / \mathrm{I}$ (normal range $<40 \mathrm{IU} / \mathrm{l}$ ) and $640 \mathrm{IU} / \mathrm{I}$ (normal range $<350 \mathrm{IU} / \mathrm{I}$ ) respectively. The blood test showed leukopenia $\left(3000 / \mathrm{mm}^{3}\right)$ and thrombocytopenia (14x104/ $\mathrm{mm}^{3}$ ). Her serum level of D-dimer was $890 \mathrm{ng} / \mathrm{ml}$ (normal range $<100 \mathrm{ng} / \mathrm{ml}$ ). Cultures of specimens of blood and sputum were sterile. Testing for antibodies to Mycoplasma pneumoniae, Chlamydia pneumoniae, Legionella pneumophila and Herpes symplex type 1 were negative.

Arterial blood gas levels measured while the patients was breathing room air revealed moderate hypoxemia $\left(\mathrm{PaO}_{2} 83\right.$ $\mathrm{mm} \mathrm{Hg})$ and hypocarbia $\left(\mathrm{PaCO}_{2} 28 \mathrm{~mm} \mathrm{Hg}\right)$. 
The ECG showed sinus tachycardia with right heart strain. Anteroposterior and lateral chest radiographs showed incomplete segmental consolidation of the right lower lobe. Computed tomography of the chest showed massive filling defects in bilateral pulmonary arteries and consolidation in the right lower lobe (Fig. 1). Doppler ultrasonography of the deep leg veins revealed no abnormality.

Her nasopharyngeal swab was tested for H1N1 virus by real-time RT-PCR and found positive. The patient was diagnosed to have pulmonary embolism with pandemic influenza A (H1N1) virus infection. A combination therapy with intravenous heparin and oseltamivir started. Two days later the patient recovered. Her fever and chest pain responded well to the treatment and D-dimer levels returned to normal.

The patient was discharged with daily coumadin and instructions to continue taking it with a target international normalized ratio (INR) of 2 to 3 . The final diagnosis was pulmonary embolism with novel influenza A (H1N1) infection. Follow-up CT scan two months following discharge showed no evidence of pulmonary embolism.

\section{Discussion}

Pulmonary illness with unusual features that include leukopenia, myalgia, thrombocytopenia, and elevated lactate dehydrogenase levels in this patient was suggestive of atypical pneumonia. However, all the agents responsible for atypical pneumonia were ruled out by serologic methods.

When this patient was admitted to our hospital, $\mathrm{H} 1 \mathrm{~N} 1 \mathrm{vi}-$ rus was endemic in our region. Since $\mathrm{H} 1 \mathrm{~N} 1$ virus infection can cause serious pulmonary illness and pulmonary embolism in young, previously healthy persons; we considered pandemic $\mathrm{H} 1 \mathrm{~N} 1$ virus infection in the differential diagnosis.

The clinical features of pandemic $\mathrm{H} 1 \mathrm{~N} 1$ virus are similar to those of seasonal influenza, although gastrointestinal properties appear to be more common with pandemic H1N1 influenza A. The most common clinical findings of the $2009 \mathrm{H} 1 \mathrm{~N} 1$ influenza A pandemic were fever, cough, sore throat, malaise,

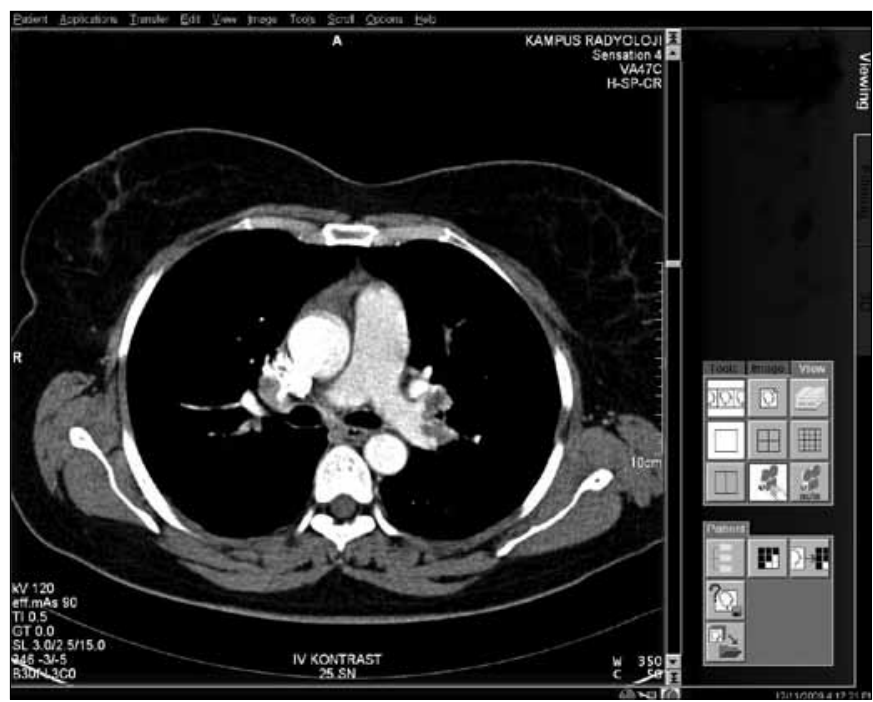

Figure 1. Chest CT showed massive filling defects in bilateral pulmonary arteries headache, vomiting and diarrhea. Other frequent findings included chills, myalgias, and arthralgias (6-8). The most common risk factors for influenza complications are chronic lung disease (asthma or chronic obstructive pulmonary disease, 37 percent), immunosuppressive conditions (17 percent), cardiac disease (17 percent), pregnancy (17 percent), diabetes mellitus (13 percent), and obesity (13 percent) (9). There were no underlying risk factors in our patient.

Most common laboratory abnormalities are elevated alanine aminotransferase (48\%), elevated aspartat aminotransferase (44\%), anemia (37\%), leukopenia (20\%), leukocytosis (18\%), thrombocytopenia (14\%), thrombocytosis (9\%) and elevated total bilirubin (5\%) (10). Relative lymphopenia without leukopenia was observed frequently (11). Mild to moderate elevations of creatine kinase and lactate dehydrogenase levels have been reported in some patients with severe illness (12). Our case had elevated serum alanine transaminase, aspartate transaminase and lactate dehydogenase levels. Leukopenia and mild thrombocytopenia were also detected in our presented case.

Infection with seasonal influenza viruses may cause severe pulmonary disease and pulmonary embolism (13). Furthermore, a report of two patients associated with influenza A $(\mathrm{H} 3 \mathrm{~N} 2)$ virus infection noted that they received a diagnosis of acute pulmonary embolism (14).

The possible association between acute respiratory tract infections caused by seasonal influenza virus and the occurrence of pulmonary thromboembolism remains unknown. However, a recent study suggest that seasonal influenza infection is not an important risk factor for pulmonary embolism (15).

Pulmonary embolism was not noted in patients hospitalized with pandemic influenza $A(\mathrm{H} 1 \mathrm{~N} 1)$ virus infection in Mexico (8), although in England, mortality associated with pandemic influenza $A(\mathrm{H} 1 \mathrm{~N} 1)$ was mostly due to respiratory conditions (76\%). The direct cause of death was recorded as pulmonary embolism in $1 \%$ of these cases (16).

However, in a study conducted in United States; of the hospitalized patients with pandemic $\mathrm{H} 1 \mathrm{~N} 1$ influenza $\mathrm{A}$ infection, $66 \%$ had pulmonary infiltrates suggestive of pneumonia or acute respiratory distress syndrome (17). Another study performed in the United States showed that the most common findings on chest radiography were patchy consolidation but chest radiographs were normal in more than half of patients with pandemic $\mathrm{H} 1 \mathrm{~N} 1$ virus. In this study; pulmonary embolism was detected by CT in $36 \%$ of the critically ill patients (5).

Additionally; the symptoms of dyspnea, tachycardia, pleuritic chest pain, elevated D-dimer levels and findings of thorax CT suggested the possibility of pulmonary embolism. Our patient had no other risk factors for pulmonary embolism that we identified.

In a study from Spain, among patients with H1N1 virus requiring mechanical ventilation, evidence of pulmonary embolism was confirmed in one patient, but, chest computed tomography scan was obtained in only $10 \%$ of these cases. Pulmonary consolidation as seen in this patient was also reported in this Spanish study (18). As a result; pandemic influenza $A$ (H1N1) per se, without risk factors, could lead to pulmonary embolism. 
Real-time reverse transcriptase ( $r R T)-P C R$ is the most sensitive and specific test for the diagnosis of pandemic $\mathrm{H} 1 \mathrm{~N} 1 \mathrm{in}$ fluenza A virus infection. PCR testing takes about 6 hours and has a sensitivity of $98 \%$, a positive predictive value of $100 \%$, and a negative predictive value of $98 \%$ (19). Our final diagnosis was made by PCR analysis as presented above.

Use of the neuraminidase inhibitors oseltamivir and zanamivir is currently the most appropriate strategy for the treatment of this disease (20). We chose to treat the patient with oseltamivir while we waited for the results of polymerasechain-reaction (PCR) assay.

Finally, clinicians should consider the 2009 pandemic influenza $A(H 1 N 1)$ virus infection, in the differential diagnosis of patients presenting with fever and respiratory illness or pulmonary embolism.

\section{Conflict of Interest}

No conflict of interest was declared by the authors.

\section{References}

1. Garten RJ, Davis CT, Russell CA, Shu B, Lindstrom S, Balish $A$, et al. Antigenic and genetic characteristics of swine-origin $2009 \mathrm{~A}(\mathrm{H} 1 \mathrm{~N} 1)$ influenza viruses circulating in humans. Science 2009;325:197-201. [CrossRef]

2. Outbreak of swine-origin influenza $A(H 1 N 1)$ virus infection - Mexico, March-April 2009. MMWR Morb Mortal Wkly Rep 2009;58:467-70.

3. Kumar A, Zarychanski R, Pinto R, Cook DJ, Marshall J, Lacroix J, et al. Critically III Patients With 2009 Influenza A(H1N1) Infection in Canada. JAMA 2009;302:1872-9. [CrossRef]

4. Gordon SM. Update on 2009 pandemic influenza A (H1N1) virus Cleveland Clinic Journal Of Medicine 2009;76:577-82. [CrossRef]

5. Agarwal PP, Cinti S, Kazerooni EA. Chest radiographic and CT findings in novel swine-origin influenza $A(\mathrm{H} 1 \mathrm{~N} 1)$ virus (S-OIV) infection. Am J Roentgenol 2009;193:1488-93. [CrossRef]

6. Dawood FS, Jain S, Finelli L, Shaw MW, Lindstrom S, Garten RJ, et al. Emergence of a novel swine-origin influenza $A(H 1 N 1)$ virus in humans. N Engl J Med 2009;360:2605-15. [CrossRef]

7. Louie JK, Acosta M, Winter K, Jean C, Schecter R, Vugia D, et al. Factors associated with death or hospitalization due to pandemic 2009 influenza A (H1N1) infection in California. JAMA 2009;302:1896-902. [CrossRef]
8. Perez-Padilla R, de la Rosa-Zamboni D, Ponce de Leon S, Hernandez $M$, Quiñones-Falconi $F$, Bautista $E$, et al. Pneumonia and respiratory failure for swine-origin influenza $A(H 1 N 1)$ in Mexico.N Engl J Med 2009;361:680-9. [CrossRef]

9. Hospitalized patients with novel influenza $A(H 1 N 1)$ virus infection - California, April-May, 2009. MMWR Morb Mortal Wkly Rep 2009;58:536-41.

10. Jain S, Kamimoto L, Bramley AM, Schmitz AM, Benoit SR, Louie $\mathrm{J}$, et al. Hospitalized patients with $2009 \mathrm{H} 1 \mathrm{~N} 1$ influenza in the United States, N Engl J Med 2009;361:1935-44. [CrossRef]

11. Cunha BA, Pherez FM, Schoch P. Diagnostic importance of relative lymphopenia as a marker of swine influenza $(\mathrm{H} 1 \mathrm{~N} 1)$ in adults. Clin Infect Dis 2009;49:1454-6. [CrossRef]

12. Perez-Padilla R, de la Rosa-Zamboni D, Ponce de Leon S, Hernan$\operatorname{dez} \mathrm{M}$, Quiñones-Falconi F, Bautista E, et al. Pneumonia and Respiratory Failure from Swine-Origin Influenza A (H1N1) in Mexico. N Engl J Med 2009;361:680-9. [CrossRef]

13. Ohrui T, Takahashi H, Ebihara S, Matsui T, Nakayama K, Sasaki H, et al. Influenza A virus infection and pulmonary microthromboembolism. J Exp Med 2000;192:81-6.

14. Abdel-Ghafar AN, Chotpitayasunohdh T, Gao Z, Hayden FG, Nguyen $\mathrm{DH}$, de Jong $\mathrm{MD}$, et al. Update on avian influenza $A$ (H5N1) virus infection in humans. N Engl J Med 2008;358:261-73. [CrossRef]

15. Van Wissen $M$, Keller TT, Ronkes B, Gerdes VE, Zaaijer $H L$, van Gorp EC, et al. Influenza infection and risk of acute pulmonary embolism. Thromb J 2007;5:16. [CrossRef]

16. Donaldson LJ, Rutter PD, Ellis BM, Greaves FE, Mytton OT, Pebody RG, et al. Mortality from pandemic A/H1N1 2009 influenza in England: public health surveillance study. BMJ 2009;339:b5213. [CrossRef]

17. Louie JK, Acosta M, Winter K, Jean C, Gavali S, Schechter R, et al. Factors associated with death or hospitalization due to pandemic 2009 influenza A (H1N1) infection in California. JAMA 2009;302:1896. [CrossRef]

18. Rello J, Rodríguez A, Ibañez P, Socias L, Cebrian J, Marques A, et al. Intensive care adult patients with severe respiratory failure caused by influenza A (H1N1)v in Spain. Crit Care 2009;13:R148. [CrossRef]

19. Ginocchio CC, Zhang F, Manji R, Arora S, Bornfreund M, Falk $\mathrm{L}$, et al. Evaluation of multiple test methods for the detection of the novel 2009 influenza A (H1N1) during the New York City outbreak. J Clin Virol 2009;45:191-5. [CrossRef]

20. Lee N, Chan PKS, Hui DS, Rainer TH, Wong E, Choi KW, et al. Viral loads and duration of viral shedding in adult patients hospitalized with influenza. J Infect Dis 2009; 200:492-500. [CrossRef] 